\title{
Environmental conditions affecting spiders in grasslands at the lower reach of the River Tisza in Hungary
}

\author{
Róbert Gallé, Norbert Vesztergom \& Tamás Somogyi
}

Gallé, R., Vesztergom, N. \& Somogyi, T. 2011: Environmental conditions affecting spiders in grasslands at the lower reach of the River Tisza in Hungary. Entomol. Fennica 22: 29-38.

The aims of the present study were to reveal the differences between grassland types, and to identify the local and landscape parameters that influence the spider assemblages at the reach of the River Tisza. The rarefied number of spider species was negatively correlated with the proportion of forests in a radius of $500 \mathrm{~m}$ around each site. A negative correlation was found between the number of grassland specialist species and the proportion of the forests, but the number of forest species increased significantly with the neighboring forest area. The relative area of neighboring forests, the number of plant species and regular flooding played major roles in shaping of the species composition of spiders. The results of the present study emphasize the importance of the effect of habitat landscape properties on spider assemblages. The structural diversity of the landscape may influence species richness and composition of the habitats.

R. Gallé, N. Vesztergom \& T. Somogyi, Department of Ecology, University of Szeged, Középfasor 52, H-6726 Szeged, Hungary; Corresponding author's email: galle.robert@gmail.com

Received 15 February 2010, accepted 3 December 2010

\section{Introduction}

In the Hungarian Great Plain, grasslands are threatened by the expansion of agricultural activity (Horváth et al. 2009). During the river regulations in the $19^{\text {th }}$ century the historical floodplain was divided by dikes into floodplain and nonflooded, protected areas. The remnants of the protected grasslands are mainly used as pastures or meadows.

These small patches are enclosed between highly modified landscape elements, i.e. arable fields and forest plantations of mainly non-native tree species. The natural disturbance of the regular flooding events and the related changes in the vegetation structure are expected to affect structural and microclimatic parameters in floodplain habitats (Ward et al. 2002, Lambeets et al. 2008, 2009).

The distribution of organisms across such a mosaic landscape is influenced by numerous factors and presumably by the complex relationships among these factors (Turner 2005).

Among the habitat features, the composition and structure of vegetation (Ysnel \& Canard 2000, Heikkinen \& MacMahon 2004) influence the species composition and diversity of the invertebrate assemblages. Plant species richness and the height of the vegetation is supposed to have a major influence on the spider assemblages, as higher plant species richness offers more diverse habitat structure and more potential sites for web building (Jeanneret et al. 2003a, Horváth et al. 2009). 
On the landscape scale, heterogeneity of the surrounding habitat patches may influence the diversity and the number of species of the assemblages at a given patch (Duelli 1997). Although numerous authors have demonstrated the significance of the spatial structure of the landscape on invertebrate assemblages (e.g. Diekötter 2008, Ricketts 2001), it is difficult to generalize the effect of the landscape heterogeneity, as various taxa react differently to the habitat and landscape features, since species ecology and dispersal abilities are different for every organism (Burel \& Baudry 1995, Jeanneret et al. 2003a).

The present study aimed at testing the effect of habitat parameters (soil humidity, regular flooding, structure and cover of the vegetation) and landscape (proportion of grasslands, forests and arable fields) on the spider assemblages, and to reveal the differences between assemblages of the floodplain and on protected grasslands. Spiders were chosen for the study as they are the most diverse and abundant predatory invertebrate group of grasslands (Wise 1993).

The following hypotheses were tested:

(1) In terms of the habitat features we expected the number of species to increase with more structured vegetation, as it is well-known that vegetation height and density is important for spiders (e.g. Greenstone 1984). We did not expect the number of species to change with regular flooding event as floodplain habitats do not necessarily harbor more species but rather exhibit different species compositions and different diversity patterns (Lambeets et al. 2009).

(2) According to Entling et al. (2007) and Lambeets et al. $(2008,2009)$ we also expected the vegetation structure, soil moisture and regular flooding to alter the species composition of spiders.

(3) As regards the effect of the landscape composition, we expected the number of species to increase with increasing proportion of forests around the study sites, as a consequence of the occurrence of forest specialist and generalist species in the grasslands (Usher et al. 1993). We also expected the number of species to increase with the increasing proportion of grasslands around the study sites, as the theory of island biogeography states that more isolated habitats retain less habitat specialist species than less isolated ones (e.g. Lövei et al. 2006).

(4) According to the above-mentioned hypotheses we expected both the proportion of forests and grasslands to influence the species composition of spider assemblages.

\section{Materials and methods}

\subsection{Study sites and sampling}

Two habitat complexes of the lower Tisza-valley were selected for sampling spider assemblages. The southern habitat complex (Vesszős) is situated near Szeged (46 $17^{\prime} 30^{\prime \prime N}$; 20 2014'20'E), where the landscape mainly consists of arable fields with small patches of grasslands, and oak and poplar forest plantations are embedded in the matrix of arable fields. The Dóc habitat complex lies $40 \mathrm{~km}$ north of Szeged (46²6'20'N; 20¹0' 40 'E), in a structurally more complex landscape. Higher proportion of semi-natural grasslands and forests occur here.

The spider assemblages were studied at six grasslands (sampling sites) in the southern habitat complex and four in the northern habitat complex, respectively. In each habitat complex, haymeadow, saline grassland, floodplain meadow, degraded grassland, and at the southern habitat complex a pair of dike-side meadows (i.e. floodplain and protected) were studied.

To sample the fauna pitfall traps were applied (diameter $65 \mathrm{~mm}$, filled with ethylene glycol as preservative, Koivula 2003, Schmidt et al. 2006). At each site three lines of traps (sampling plots) were placed, each line consisted of five traps keeping a distance of $4 \mathrm{~m}$ between them. The average distance between the lines was $150 \mathrm{~m}$. Prior to the data analysis, the data of the five traps were pooled. We expected an underestimation of the abundance of web-building species, as pitfall traps measure the activity-density of species at the ground level, thus they capture the spiders with an active hunter lifestyle on the soil surface more efficiently (Topping \& Sunderland 1992, Urák \& Samu 2008). However, pitfall traps offer 
a relatively good alternative for comparing the activity-density of epigaeic spider fauna of different habitats (Scmidt et al. 2005, Öberg et al. 2007). The traps were kept open for four 2 -week sampling periods (27 May-13 June, 30 June-15 July, 16-30 Aug., 18 Sept.-01 Oct.) in 2007 to cover the main activity period of the spider species. The data of the four sampling periods were pooled.

To characterize the structure of the vegetation, the number of plant species and the total cover of the vegetation at the ground level, at 10 and $40 \mathrm{~cm}$ above the ground, were measured within $1 \times 1$ meter quadrates near the traps, as structurally complex habitats may provide more potential sites for web building, and because spiders are strongly influenced by the habitat structure (Schwab et al. 2002).

To assess the features of the landscape, the proportion of land-use types was measured in a radius of $500 \mathrm{~m}$ around each site, based on aerial photographs (i.e. grasslands, forests and arable fields), as several studies suggest that landscape composition at scales of $500 \mathrm{~m}$ radius can be relevant for spiders (Clough et al. 2005, Schmidt et al. 2005). The remaining landscape elements (e.g. surface of the river) were not entered into the analysis in order to decrease the number of factors which were tested.

\subsection{Data analysis}

Habitat structure affects the trappability of spider individuals, which may result in biased data for studies comparing species richness of habitats with different structures (Melburne 1999). Due to the different habitat properties of the sampling plots and the large variation in the number of individuals recorded over the trapping period, rarefaction was used to standardise the number of species recorded within each of the sampling plots (Heck et al. 1975, Gotelli \& Colwell 2001).

As regards hypothesis 1 and 3, the univariate regression tree method (URT) was used to gain insight into the structure of the data and identify the interactions between the variables (Tree Package, Ripley 2009). The method performs a binary recursive partitioning of the dataset. It also offers the opportunity to identify the influential explanatory variables (Crawley 2007).
To assess the significance of their effect, the explanatory variables suggested by the URT method were subjected to a linear mixed-effect model with nested random effects using the library nlme in R (Pinheiro et al. 2007). The effect of the different habitat complexes and sampling sites were used as random effects and the explanatory variables suggested by the regression tree method were used as fixed effects in the mixed effect linear model (Crawley 2007). The collected species were categorized according to their habitat requirements (Buchar \& Ruzicka 2002, Szita et al. 2006, Schmidt \& Hanggi 2007, Batáry et al. 2008). The significant landscape scale parameters were included in two subsequent linear models to assess their effects on the number of forest and grassland specialist species.

Rényi's diversity ordering was used to compare the diversity of the floodplain and protected habitats (hypothesis 1). Diversity ordering provides the diversity profiles of the assemblages. These curves consist of a series of diversity indices, as the scale parameter is changed, including indices sensitive to both rare and abundant species (Carranza et al. 2007). An assemblage is considered to be more diverse than another if its profile lies above and they do not intersect (Tóthmérész 1995). R software (R Development Core Team 2007) with the BiodiversityR Package (Kindt 2008) was used for the calculations.

The influence of the measured explanatory variables was tested on spider assemblages (hypothesis 2 and 4) by using the multivariate regression tree (MRT) method. This method is an extension of univariate regression trees having multivariate response (De'ath 2002). MRT does not assume particular form of relationship between species abundances and explanatory variables. This method can be used to identify interactions between explanatory variables (De'ath 2002, 2010).

The size of the tree was selected based on the minimum tree size that falls below $1 \mathrm{SE}$ of the minimum cross-validation estimate. The final tree size was selected based on the frequently occurring number of leaves from 100 individual trees (Work et al. 2004).

The species that characterize each leaf and node of the MRT were identified using the indicator species index (IndVal) based on the relative 


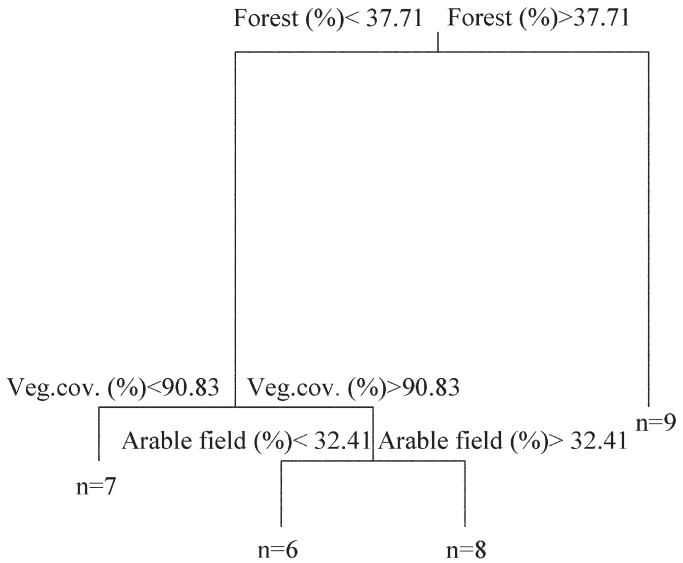

Fig. 1. Univariate regression tree for the rarefied species richness. Node 1 is based on Forest (\%), the proportion of forests around the sampling plots; node 2 on Veg. cov. (\%), the total vegetation cover; node 3 on Arable field (\%), the proportion of the arable field. The different lengths of the lines following each split are proportional to the variance explained by the split. The numbers below each leaf show the number of samples falling into that leaf.

abundance and relative frequency of occurrence (Dufrene \& Legendre 1997, De'ath 2002).

\section{Results}

A total number of 3547 spider specimens were collected, representing 95 species in 17 families (Appendix, downloadable from http://ojs.tsv.fi/ index.php/entomolfennica/). The species richness of grassland patches ranged between 23 and
34 , thus the species composition differed considerably between the studied grasslands.

\subsection{Hypothesis 1: The influence of habitat features on the rarefied number of the species}

According to the univariate regression tree method the total vegetation cover is the only habitat parameter that had a possible influence on the rarefied number of species in case of higher proportion of forests (Fig. 1). However, the vegetation cover had no significant effect on the rarefied number of the species according to the results of the linear mixed-effect model $\left(t_{17}=-0.361 ; p=\right.$ 0.722 )

The diversity profiles of the spider assemblages inhabiting the floodplain and protected habitats are given in Fig 2. The curve for the protected grasslands runs above that for the floodplain grasslands and the two curves do not intersect. Thus, the assemblages of the protected grasslands were more diverse for the whole range of the scale parameter.

\subsection{Hypothesis 2 . The influence of habitat features on the species composition}

The cross validation of 100 MRT trees yielded trees of two, four and five leaves, 11, 46 and 40 times, respectively, with three trees resulting in 6-8 leaves. The four-leaf tree is presented in Fig 3. The MRT, indicating the influence of the num-

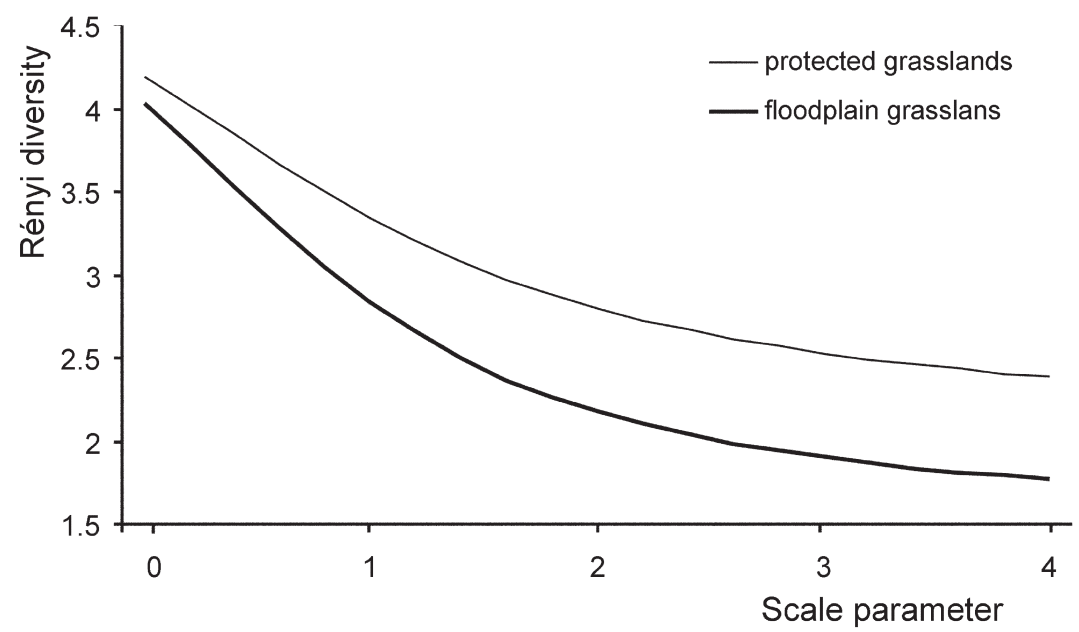

Fig. 2. The results of Rényi's diverisity ordering. The diversity profiles do not intersect, thus the assemblages of the protected grasslands are more diverse. 


\begin{tabular}{|c|c|c|c|c|c|}
\hline \multirow[b]{3}{*}{$\begin{array}{l}\text { No. of plant } \\
\text { species }>=13\end{array}$} & \multicolumn{3}{|c|}{ Forest $(\%)<37.71$, Forest $(\%)>=37.71$} & \multirow{3}{*}{\multicolumn{2}{|c|}{ Floodplain }} \\
\hline & \multirow{2}{*}{\multicolumn{2}{|c|}{$\begin{array}{l}\text { No. of plant } \\
\text { species }<13\end{array}$}} & \multirow[b]{2}{*}{ Protected } & & \\
\hline & & & & & \\
\hline \multirow[t]{2}{*}{ Thare $(0$} & $\begin{array}{l}\text { le } 2 \\
27) *\end{array}$ & $\begin{array}{l}\text { H rad }(0.749) * * \\
M \operatorname{ros}(0.555) * * \\
G \operatorname{luc}(0.547) * \\
G \operatorname{ruf}(0.555) * \\
Z \operatorname{seg}(0.444) * \\
Z \text { lon }(0.514) *\end{array}$ & $\begin{array}{l}\text { No } \\
D \text { con }(0 \\
P \text { ala }(0 . \\
Z \text { lat }(0.5 \\
\text { O sim }(0\end{array}$ & $\begin{array}{l}\text { e } 3 \\
37) * * \\
78) * * \\
2) * \\
) *\end{array}$ & $\begin{array}{l}\text { O api }(0.994) * * * \\
\text { A ele }(0.666) * * \\
\text { A leo }(0.666) * * \\
\text { A mac }(0.825) * * \\
\text { E den }(0.578) * * \\
P \text { lat }(0.679) * * \\
\text { A hum }(0.5) *\end{array}$ \\
\hline & & $1=9$ & $n=3$ & $\mathrm{n}=6$ & $\begin{array}{l}D \text { lut }(0.476) * \\
P \text { ame }(0.333) * \\
P \text { cri }(0.585) * \\
P \text { deg }(0.550) * \\
P \text { pro }(0.602) * \\
T \text { str }(0.512) * \\
Z \text { mun }(0.5) *\end{array}$ \\
\hline
\end{tabular}

Fig. 3. Multivariate regression tree for spiders. Bray-Curtis dissimilarity was used for splitting. The final tree size was selected based on the most frequently occurring number of leaves from 100 individual trees. The numbers below each leaf show the number of samples falling into that leaf. The abbreviated names of species with significant indicator value are given at each leaf, the indicator values are given in parenthesis ${ }^{* * *} p<0.001,{ }^{* *} p<0.01,{ }^{*}$ $p<0.05)$. Abbreviations: T are: Thanatus arenarius, $H$ rad: Hogna radiata, $M$ ross: Micaria rossica, G luc: Gnaphosa lucifuga, Z seg: Zelotes segrex, Z lon: Z. longipes, D con: Diplostyla concolor, $P$ ala: Pardosa alacris, Z lat: Z. latreillei, O sim: Ozyptila simplex, O api: Oedothorax apicatus, A ele: Antistea elegans, A leo: Arctosa leopardus, E den: Erigone dentipalpis, $P$ lat: Pirata latitans, A. hum: Araeoncus humilis, D lut: Drassyllus lutetianus, $P$ ame: P. amentata, P cri: P. cribrata, P deg: Pachygnatha degeeri, P pro: Pardosa proxima, T str. T. striatus, $Z$ mun: $Z$. mundus.

ber of plant species (node 2, Fig. 3), accounted for $12.9 \%$ of the total variance and the regular flooding events (node 3, Fig. 3) accounted for $8.9 \%$ of the total variance.

The IndVal analysis identified one indicator species of the first leaf (Thanatus arenarius Thorell, 1872). This species lives in open, dry habitats.

For the second leaf the IndVal analysis identified 6 species. These spiders occur in the natural alkali grasslands of the Great Hungarian Plain (Szita et al. 2006, Batáry et al. 2008).

For third leaf the IndVal analysis identified two forest specialist species (Pardosa alacris (C.L. Koch, 1833) and Diplostyla concolor (Wider, 1834)), and the generalist Zelotes latreillei (Simon, 1878) and Ozyptila simplex (O.P.-Cambridge, 1862) (Buchar \& Ruzicka 2002).
For the fourth leaf we identified 14 indicator species. Out of these spiders the generalist Oedothorax apicatus (Blackwall, 1850), Erigone dentipalpis (Wider, 1834) and Pachygnatha degeeri Sundevall, 1830 occur under the regularly disturbed conditions of agricultural fields and 11 species are associated with wet meadows and pond margins (Buchar \& Ruzicka 2002, Schmidt \& Hanggi 2007).

\subsection{Hypothesis 3. The effect of landscape scale parameters on the rarefied number of the species}

According to the URT the two most influential parameters were the proportion of forests and arable fields (Fig. 1). As predicted, the proportion of 
forests had a significant effect according to the subsequent GLMM $\left(t_{17}=-2.228, p=0.039\right)$. However, no significant relationship was found between the proportion of arable fields and the rarefied number of the species $\left(t_{17}=-1.801, p=\right.$ $0.089)$. The subsequent linear models revealed the significant negative effect of forests on the number of grassland specialist species $\left(t_{19}=-\right.$ $2.166, p=0.043)$ and the marginally significant positive effect on the forest specialist species $\left(t_{19}\right.$ $=2.024, p=0.057$ ).

\subsection{Hypothesis 4. The influence of landscape scale parameters on the composition of species}

The MRT analysis identified only one influential landscape scale parameter. The proportion of forests in a radius of $500 \mathrm{~m}$ around each site (Fig. 3, node 1) accounted for $26.2 \%$ of the total variance.

\section{Discussion}

\subsection{No influential habitat parameter on the rarefied number of the species, but there is a higher diversity at the protected grasslands}

Although numerous studies have demonstrated the effect of plant species richness and habitat structure on the number of species and the diversity of spiders (e.g. Jeanneret et al. 2003b, Tews et al. 2004), we found no significant relationship between the vegetational parameters and the rarefied number of the species. Gallé \& Torma (2009) and Gallé et al. (2010) demonstrated that different habitat types may exhibit spider assemblages with similar number of species but different species compositions. Thus, for a detailed study into the relationship between the spiders and the habitat parameters the examination of the species abundance data is required in order to assess the impact of these parameters on the spider assemblages without the loss of information when summarizing the data on the assemblages in a single value such as species richness (Jeanneret et al. $2003 \mathrm{~b}, \mathrm{c})$.

In accordance with Bell et al. (1999) and Bonn et al. (2002), our results also indicate that water regime play an important role in the shaping of the diversity of spider assemblages at riverine landscapes. Numerous studies have demonstrated that spiders are particularly sensitive to flooding. The spider diversity is not only influenced by the occurrence of flooding events but also by the duration and frequency of these events (Uetz 1976, Paetzold et al. 2008).

\subsection{The number of plant species and the regular flooding events influenced the species composition of spiders}

The vegetation and flooding events are constraints for spider occurrence, indicating the importance of the quality of local habitats. In lowland floodplains, flooding dynamics determine the composition of the species and the structure of the vegetation which in turn influence the composition of spider fauna (Ballinger et al.2005). As in most habitat types, vegetation plays a major role in determining the physical parameters of the habitat, and therefore, has a significant influence on the distributions of invertebrate species (Bonte 2002, Tews et al. 2004). Gravesen (2000) and Lambeets et al. (2006) also support the hypothesis that a combination of flooding intensity and vegetation structure is important factor for the species composition of spiders in wet grassland areas.

Sabo et al. (2005) reviewed the literature on the species richness and assemblage composition of flooded and non-flooded habitats. In accordance with the results of the present study they found that the species composition differs between the regularly flooded and non-flooded habitats. This can increase the regional species richness. Several studies have confirmed the importance of fluvial dynamics affecting spider assemblages by altering the habitat conditions (Bonn et al. 2002, Paetzold et al. 2008).

At regularly flooded habitats Lambeets et al. (2009) found that the dispersal ability of species plays a prominent role in structuring carabid and spider assemblages, thus life-history traits affect species composition of spiders. Rothenbücher and Schaefer (2006) studied the impact of flooding on invertebrate assemblages. They distinguished two types of adaptation in invertebrates: 
submersion tolerance and regular migration before and after the flooding. Most spiders overwinter at juvenile or adult stages (Pekár 1999). These stages of terrestrial arthropods are less flood-resistant than are their eggs, thus they are not able to tolerate long winter submersions. Rothenbücher and Schaefer (2006) demonstrated that the floodplain spider fauna consists of species immigrating with receding water levels. The abundance of cursorial spiders depends on the proximity and connectivity of natural habitats, possibly for seasonal migration towards hibernation sites (Bonte et al. 2003, Lambeets et al. 2008), while good ballooners are able to colonize form greater distances (Bonte et al. 2002).

Although the IndVal analysis identified 14 species associated with floodplain grasslands, many species of the floodplain habitats are opportunistic species from the surrounding nonflooded habitats that can colonize after the flooding events (Adis \& Junk 2002).

\subsection{The proportion of forests had a significant negative effect on the rarefied number of the species}

In accordance with the results of the present study, Clough et al. (2005) reported that the rarefied number of species is influenced by the landscape parameters. Öberg et al. (2007) and Drapela et al. (2008) found that a higher proportion of forests in the surrounding landscape were associated with a higher number of observed spider species, as forests may serve as source habitat for spiders. Our results also support this hypothesis as we found increasing number of forest specialist species with the proportion of surrounding forests. Species arriving in grasslands from forests are likely to add new species to the spider assemblage, as forests and open habitats are home to contrasting spider assemblages (Entling et al. 2007, Drapela et al. 2008).

The effect of forests on the grassland specialist species is possibly due to the fact that smaller, more isolated fragments retain fewer habitat species than larger less isolated ones (e.g. Lövei 2006). Several papers emphasize the effects of surrounding habitats on the dispersal of species (Bonte et al. 2004, Thorbek \& Topping 2005) and thus the isolation of the habitats. Higher proportion of forests may serve as dispersal barriers for grassland specialist species.

\subsection{The fauna of the surrounding forests influence the species composition of spiders}

According to the MRT landscape composition is important in determining the species composition in grasslands. Similarly to our results, numerous studies have shown that landscape variables are important determinants of species composition of spiders (e.g. Öberg et al. 2007, Batáry et al. 2008, Schmidt et al. 2008). The IndVal analyses identified two forest specialist species $(P$. alacris and $D$. concolor) at non-flooded grasslands with a high proportion of surrounding forests, and according to the linear models the number of forest specialist species increased and the number of grassland specialist species decreased with the proportion of surrounding forests. Although Schmidt et al. (2005) found no significant correlation between the percentage of forests and spider assemblages, Kajak (2007) demonstrated that forests influence the species composition of cereal fields by enhancing the number and abundance of forest specialist species. She also found significant effect of forest age and naturalness.

Landscape scale forestry operations may affect the diversity and species composition of the surrounding grassland habitats by altering the proportion or the habitat quality of forests. This emphasizes the importance of the landscape-level approach to nature conservation.

\section{Conclusions}

In the present study we have assessed the compositional differences of spider assemblages of various grassland types and the effects of habitat and landscape properties on the rarefied species richness and composition of spiders. Lowland floodplain habitats are of high conservational value, as their associated arthropod fauna consists of specialist and rare species (Rothenbücher \& Schaefer 2004). Even small fragments play an important role in maintaining the regional diversity of spiders, as they are not entirely isolated, because 
spiders are especially successful in dispersal (Horváth et al. 2009).

A total number of 95 species were collected, and the species richness of grassland patches ranged between 23 and 34, thus the species composition differed considerably between the studied grasslands. Our results suggest that beside the conservation of floodplain grasslands, the maintenance of diversity of grassland habitats is also essential for preserving the regional species pool of invertebrates.

Acknowledgements. We would like to thank László Körmöczi and Márta Zalatnai for their help with the botanical surveys, Gábor Laskay for the linguistic correction of the manuscript. We would also acknowledge Katja Matveinen-Huju and an anonymous Referee for the considerable efforts in suggesting improvements in the manuscript. The present study was supported by NKFP 6/013/2005 grant and the Regional University Knowledge Centre for Environmental and Nanotechnology, University of Szeged.

\section{References}

Adis J. \& Junk, W. J. 2002: Terrestrial invertebrates inhabiting lowland river floodplains of Central Amazonia and Central Europe: a review. - Freshwater Biology 47: 711-731.

Ballinger, A., Mac Nelly, R. \& Lake, P. S. 2005: Immediate and longer-term effects of managed flooding on floodplain invertebrate assemblages in south-eastern $\mathrm{Au}-$ stralia: generation and maintenance of a mosaic landscape. - Freshwater Biology 50: 1190-1205.

Batáry, P., Kovács, A. \& Báldi, A. 2008: Management effects on carabid beetles and spiders in Central Hungarian grasslands and cereal fields. - Community Ecology 9: 247-254.

Bell, D., Petts, D. E. \& Sadler, J. P. 1999: The distribution of spiders in the wooded riparian zone of three rivers in Western Europe. - Regulated Rivers: Research \& Management 15: 140-158.

Bonn, A., Hagen, K. \& Reiche, D. W. 2002: The significance of flood regimes for carabid beetle and spider communities in riparian habitats - a comparison of three major rivers in Germany. - River Research and Applications 18: 43-64.

Bonte, D., Baert, L. \& Maelfait, J.-P. 2002: Spider assemblage structure and stability in a heterogeneous coastal dune system (Belgium). - Journal of Arachnology 30: $331-343$.

Bonte, D., Lens, L., Maelfait, J.-P., Hoffmann, M. \& Kuijken, E. 2003: Patch quality and connectivity influence spatial dynamics in a dune wolfspider. - Oecologia 135:227-233.

Bonte, D., Baert, L., Lens, L. \& Maelfait, J.-P. 2004: Ef- fects of aerial dispersal, habitat specialisation, and landscape structure on spider distribution across fragmented grey dunes. - Ecography 27: 343-349.

Buchar, J. \& Ruzicka, V. 2002: Catalogue of Spiders of the Czech Republic. - Peres Publishers: Praha, Czech Republic. pp: 1-349.

Burel, F. \& Baudry, J. 1995: Species biodiversity in changing agriculture landscapes: A case study in the Pays d'Auge, France. - Agriculture Ecosystems and Environment 55: 193-200.

Carranza, M. L., Acosta, A. \& Ricotta, C. 2007: Analyzing landscape diversity in time: The use of Rènyi's generalized entropy function. - Ecological Indicators 7: 505-510.

Clough, Y., Kruess, A. \& Tscharntke, T. 2005: Spider diversity in cereal fields: comparing local, landscape and regional scales. - Journal of Biogeography 32: $2007-$ 2014.

Crawley, M. J. 2007: The R Book. — John Wiley: New York pp: 627-685.

De'ath, G. 2002: Multivariate regression trees: a new technique for modeling species-environment relationships. - Ecology 83: 1105-1117.

De'ath, G. 2010: mvpart: Multivariate partitioning. R package version 1.3-1. - [www document] URL http://CRAN.R-project.org/package=mvpart (Site visited on 14 August 2010.)

Diekötter, T., Billeterand, R. \& Crist, T. O. 2008: Effects of landscape connectivity on the spatial distribution of insect diversity in agricultural mosaic landscapes. Basic and Applied Ecology 9: 298-307.

Drapela, T., Moser, D., Zaller, J. G. \& Frank, T. 2008: Spider assemblages in winter oilseed rape affected by landscape and site factors. - Ecography 31: 254-262.

Duelli, P. 1997: Biodiversity evaluation in agricultural landscapes: An approach at two different scales. Agriculture Ecosystems and Environment 62: 81-91.

Dufrene, M. \& Legendre, P. 1997: Species assemblages and indicator species: the need for a flexible asymmetrical approach. - Ecological Monographs 67: 345366.

Entling, W., Schmidt, M. H., Bacher, S., Brandl, R. \& Nentwig, W. 2007: Niche properties of Central European spiders: shading, moisture and the evolution of the habitat niche. - Global Ecology and Biogeography 16: 440-448.

Gallé, R. \& Torma, A. 2009: Epigeic spider (Araneae) assemblages of natural forest edges in the Kiskunság (Hungary). - Community Ecology 10: 146-151.

Gallé, R., Torma, A. \& Körmöczi, L. 2010: Small-scale effect of habitat heterogeneity on invertebrate assemblages in Hungarian sandy grasslands. - Polish Journal of Ecology 58: 333-346.

Gotelli, N. J. \& Colwell, R. K. 2001: Quantifying biodiversity: procedures and pitfalls in the measurement and comparison of species richness. - Ecology Letters 4: 379-391.

Gravesen, E. 2000: Spiders (Araneae) and other invertebrate groups as ecological indicators in wetland area. Ekologika (Bratislava) 19: 39-42. 
Greenstone, M. H. 1984: Determinants of web spider species diversity: vegetation structural diversity vs. prey availability. - Oecologia 62: 299-304.

Heck, K. L, van Belle, G. \& Simberloff, D. 1975: Explicit calculation of the rarefaction diversity measurement and the determination of sufficient sample size. Ecology 52: 1459-1461.

Heikkinen, M. W. \& MacMahon, J. A. 2004: Assemblages of spiders on models of semi-arid shrubs. - The Journal of Arachnology 32: 313-323.

Horváth, R., Magura, T., Szinetár, Cs. \& Tóthmérész, B. 2009: Spiders are not less diverse in small and isolated grasslands, but less diverse in overgrazed grasslands: A field study (East Hungary, Nyírség). - Agriculture, Ecosystems and Environment 130: 16-22.

Jeanneret, Ph., Schüpbach, B., Pfiffner, L., Herzog, F. \& Walter, Th. 2003a: The Swiss agri-environmental programme and its effects on selected biodiversity indicators. - Journal for Nature Conservation 11: 213-220.

Jeanneret, Ph., Schüpbach, B., Pfiffner, L. \& Walter, Th. 2003b: Arthropod reaction to landscape and habitat features in agricultural landscapes. - Landscape Ecology 18: 253-263.

Jeanneret, Ph., Schüpbach, B. \& Luka, H. 2003c: Quantifying the impact of landscape and habitat features on biodiversity in cultivated landscapes. - Agriculture, Ecosystems and Environment 98: 311-320.

Kajak, A. 2007: Effects of forested strips on spider assemblages in adjacent cereal fields: dispersal activity of spiders. — Polish Journal of Ecology 55: 691-704.

Kindt, R. 2008: The BiodiversityR Package. R package ver. 1.2. — [www document] URL http://cran.r-project.org/. (Site visited on 14 August 2010).

Koivula, M., Kotze, D. J., Hiisivuori, L. \& Rita, H. 2003: Pitfall trap efficiency: do trap size, collecting fluid and vegetation structure matter? - Entomologica Fennica 14: $1-14$

Lambeets, K., Bonte, D., Van Looy, K., Hendrickx, F. \& Maelfait, J.-P. 2006: Synecology of spiders (Araneae) of gravel banks and environmental constraints along a lowland river system, the Common Meuse (Belgium, the Netherlands) - In: Deltshev C \& Stoev P (eds.), European Arachnology 2005 Acta Zoologica Bulgarica Suppl.1, pp: 137-149.

Lambeets, K., Hendrickx, F., Vanacker, S., Van Looy, K., Maelfait, J.-P. \& Bonte, D. 2008: Assemblage structure and conservation value of spiders and carabid beetles from restored lowland river banks. - Biodiversity and Conservation 17: 3133-3148.

Lambeets, K., Vandegehuchte, M. L., Maelfait, J.-P. \& Bonte, D. 2009: Integrating environmental conditions and functional life history traits for riparian arthropod conservation planning. - Biological Conservation 146: 625-637.

Lövei, G. L., Magura, T., Tóthmérész, B., Ködölöcz, V. 2006: The influence of matrix and edges on species richness patterns of ground beetles (Coleoptera: Carabidae) in habitat islands. - Global Ecology and. Biogeography 15: 283-289.

Melbourne, B. A. 1999: Bias in the effect of habitat structu- re on pitfall traps: an experimental evaluation. - Australian Journal of Ecology 24: 228-239.

Öberg, S., Ekbom, B. \& Bommarco, R. 2007: Influence of habitat type and surrounding landscape on spider diversity in Swedish agroecosystems. - Agriculture, Ecosystems and Environment 122: 211-219.

Paetzold, A., Yoshimura, C. \& Tockner, K. 2008: Riparian arthropod responses to flow regulation and river channelization. - Journal of Applied Ecology 45: 894 903.

Pearce, J. L. \& Venier, L. A. 2006: The use of ground beetles (Coleoptera: Carabidae) and spiders (Araneae) as bioindicators of sustainable forest management: A review. - Ecological Indicators 6: 780-793.

Pekár, S. 1999: Some observations on overwintering of spiders (Araneae) in two contrasting orchards in the Czech Republic. - Agriculture, Ecosystems and Environment 73: 205-210.

Pinheiro, J., Bates, D., DebRoy, S. \& Sarkar, D. 2007: nlme: Linear and nonlinear mixed effects models. $\mathrm{R}$ package version 3, 1-86. - [www document] URL http:/ftp.uni-bayreuth.de/math/statlib/R/CRAN/doc/ packages/nlme.pdf(Site visited on 14 February 2010).

R Development Core Team. 2007: R: A Language and Environment for Statistical Computing. R Foundation for Statistical Computing, Vienna. - [www document] URL http://www.R-project.org. (Site visited on 14 August 2010).

Ricketts, T. H. 2001: The matrix matters: effective isolation in fragmented landscapes. - The American Naturalist 158: 87-99.

Ripley, B. 2009: Tree: Classification and regression trees. R package version 1.0-27. - [www document] URL http://CRAN.R-project.org/package=tree (Site visited on 14 August 2010).

Rothenbücher, J. \& Schaefer, M. 2006: Submersion tolerance in floodplain arthropod communities. - Basic and Applied Ecology 7: 398-408.

Sabo, J. L., Sponseller, R., Dixon, M., Gade, K., Harms, T., Heffernan, J., Jani, A., Katz, G., Soykan, C., Watts, J. \& Welter, J. 2005: Riparian zones increase regional species richness by harboring different, not more, species. - Ecology 86: 56-62.

Samu, F., Sunderland, K. D. \& Szinetár, Cs. 1999: Scaledependent dispersal and distribution patterns of spiders in agricultural systems: a review. - Journal of Arachnology 27: 325-332.

Schmidt, M. H. \& Hänggi, A. 2007: Zelotes mundus (Araneae: Gnaphosidae) in the Camargue: a continental species reaches the western Mediterranean coast. Bulletin of the British Arachnological Society 14: 27 29.

Schmidt, M. H., Roschewitz, I., Thies, C. \& Tscharntke, T. 2005: Differential effects of landscape and management on diversity and density of ground-dwelling farmland spiders. - Journal of Applied Ecology 42: 281-287.

Schmidt, M. H., Clough, Y., Schulz, W., Westphalen, A., Tscharntke, T. 2006: Capture efficiency and preserva- 
tion attributes of different fluids in pitfall traps. Journal of Arachnology 34: 159-162.

Schmidt, M. H., Thies, C., Nentwig, W. \& Tscharntke, T. 2008: Contrasting responses of arable spiders to the landscape matrix at different spatial scales. - Journal of Biogeography 35: 157-166.

Schwab, A., Dubois, D., Fried, P. M \& Edwards, P. J. 2002: Estimating the biodiversity of hay meadows in northeastern Switzerland on the basis of vegetation structure. - Agriculture, Ecosystems and Environment 93: 197-209.

Szita, É., Samu. F., Szinetár, Cs., Dudás, Gy., Botos, E., Horváth, R. \& Szalkovszki, O. 2006: New data on the occurence of Gnaphosa rufula (L. Koch, 1866) and Gnaphosa mongolica Simon, 1895 in Hungary (Araneae: Gnaphosidae) - In: Deltschev, C. \& Stoev, P. (eds.), European Arachnology 2005 pp. 329-334.

Tews, J., Brose, U., Grimm, V., Tielbörger, K., Wichmann, M. C., Schwager, M. \& Jeltsch, F. 2004: Animal species diversity driven by habitat heterogeneity/diversity: the importance of keystone structures. - Journal of Biogeography 31: 79-92.

Thorbek, P. \& Topping, C. J. 2005: The inuence of landscape diversity and heterogeneity on spacial dynamics of agrobiont linyphiid spiders: An individual based model. - BioControl, 50: 1-33.

Topping, C. J. \& Sunderland, K. D. 1992: Limitations to the use of pitfall traps in ecological studies exemplified by a study of spiders in a field of winter wheat. Journal of Applied Ecology 29: 485-491.

Tóthmérész, B. 1995: Comparsion of different methods for diversity ordering. - Journal of Vegetation Science 6: 283-290.

Turner, M. G. 2005: Landscape ecology: What is the state of the science? - Annual Review of Ecology, Evolution, and Systematics 36: 319-44.

Uetz, G. W. 1976: Gradient analysis of spider communities in a streamside forest. - Oecologia 22: 373-385.

Urák, I. \& Samu, F. 2008: Contribution to the spider fauna of the Mohoş peat bog from Transylvania, with some new data for Romania. - North-Western Journal of Zoology 4: 50-60.

Usher, M., Field, J. P., Bedford, S. E., 1993: Biogeography and diversity of ground-dwelling arthropods in farm woodlands. - Biodiversity Letters 1: 54-62.

Vasques, G. M., Grunwald, S. \& Sickman, J. O. 2008: Comparison of multivariate methods for inferential modeling of soil carbon using visible/near-infrared spectra. - Geoderma: 146: 14-25.

Ward, J. V., Tockner, K., Arscott, D. B. \& Claret, C. 2002 : Riverine landscape diversity. - Freshwater Biology 47: 517-539.

Wise, D. H. 1993: Spiders in ecological webs. - Cambridge University Press. pp: 1-328.

With K. A, Pavuk, D. M., Worchuck, J. L, Oates, R. K. \& Fisher, J. L. 2002: Threshold effects of landscape structure on biological control in agroecosystems. Ecological Applications 12: 52-65.

Work, T. T., Shorthouse, D. P., Spence, J. R., Volney, W. J. A. \& Langor, D. 2004: Stand composition and structure of the boreal mixedwood and epigaeic arthropods of the Ecosystem Management Emulating Natural Disturbance (EMEND) landbase in northwestern Alberta. — Canadian Journal of Forest Research 34: 417-430.

Ysnel, F. \& Canard, A. 2000: Spider biodiversity in connection with the vegetation structure and the foliage orientation of hedges. - Journal of Arachnology 28: 107-114. 